\title{
EDITORIAL
}

\section{Revista Brasileira de Fisioterapia na Scientific Electronic Library Online - SciELO!}

É com imensa alegria que comunicamos que a Revista Brasileira de Fisioterapia foi incluída na Coleção SciELO em junho de 2006! Queremos compartilhar esse momento com todos vocês que tornaram essa meta uma realidade: editores, revisores, autores e secretaria da Revista! Essa conquista apenas foi possível pelo trabalho árduo dos autores que submeteram artigos relevantes e de qualidade científica; revisores que deixaram o seu trabalho individual para efetuarem pareceres consistentes e úteis na seleção e aprimoramento dos artigos; e editores que contribuíram para a melhoria contínua da política editorial da Revista! Essa conquista precisa ser também creditada ao apoio decisivo do CREFITO-3, que viabilizou financeiramente a ampliação de nossa periodicidade, a versão on-line, e a versão em inglês da Revista.

Essa nova indexação é um passo fundamental na consolidação de nossa Revista, e sinaliza que nossa empreitada precisa continuar. Nossa próxima meta passa a ser as indexações internacionais (Medline,ISI) e, para tal, um aprimoramento contínuo da política editorial, assim como, o apoio financeiro de entidades de classe, torna-se imprescindível.

Convidamos todos a participar com envolvimento crescente nas atividades da Revista Brasileira de Fisioterapia!

\author{
Helenice Jane Cote Gil Coury \\ Editora \\ Revista Brasileira de Fisioterapia
}

